\title{
IRAN'S OIL AND GAS LEGAL FRAMEWORK: FROM EXPLORATION TO REVOLUTION
}

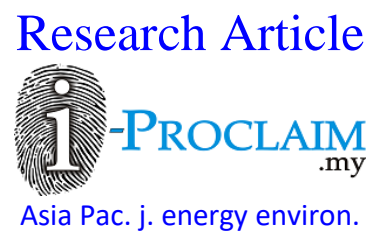

\section{Mahmoud Fard Kardel}

\author{
Department of Law, Western Sydney University, AUSTRALIA \\ *Email for Correspondence: M.FardKardel@ westernsydney.edu.au
}

Abstract

The main purpose of this article is to examine Iran's legal and contractual framework for their petroleum, oil and gas industry. Basically, the legal and contractual framework of the Iranian oil and gas industry has been classified into three periods. The first period is from the exploration and discovery of oil in Iran to nationalisation (1901-1951), the second period is from nationalisation to revolution (1951-1979), and the third period is from revolution to the present day (197920016). Because each period has its own features and importance two articles will examine this topic. The first period (from exploration to nationalisation, 1901-1951), and second period (from nationalisation to revolution, 1951-1979), has been examined in this article with legal and comparative analysis, and the third period (1979-2016) will be covered in a later article.It should be mentioned that each contractual framework was a turning point regarding to opportunities and circumstances that they have been in that time and also each of those petroleum contractual regimes were a step toward to contractual framework evolution in Iran.

Key words

Legal framework, Petroleum law, Iran, Oil and gas contracts

\section{INTRODUCTION}

In one hand considering the importance of foreign investment in the Iran's oil and gas field and on the other hand given the recent lift of petroleum sanction against Iran, it is timely to revisit the development of the oil and gas legal framework in Iran. So, in this study the survey of applicability of difference legal framework as one of the most important international investment systems is of great significance. The historical and legal framework of the Iranian oil and gas industry from exploration to the Islamic revolution (1901-1979) has generally been considered into two parts. The first section consists of the individually negotiated agreements that had started the discovery and exploration of oil in Iran (1901) to nationalisation (1951). The most important feature of this period was a lack of legal grounds and the prevalence of concessions. The second section was from the nationalisation of the oil and gas industry in 1951 until the Islamic revolution in 1979. The most significant point of this period that is any oil and gas contract is coincident of law and legislation.

\section{From Exploration to Nationalisation (1901-1951)}

Since the exploration of Iran's oil until the nationalisation of Iran's oil industry by parliament in 1951, there was no particular legislative framework, contractual form and agreements, except those individually negotiated with no preconditions. The first system governing in the history of Iran followed the pattern of concession, taking into consideration the current structure of oil contracts at that time. In other words, there were no existing legal frameworks in place during the negotiating process between the two parties. Normally, the concessions were typically signed between Shah of Iran (Iranian ruler) and foreign individuals or companies like any similar oil producing countries at the time. The Darcy Concession and the 1933 Concession agreement were the two main agreements which were entered into before the nationalization (Nasrollahi Shahri, 2010).

\section{D'Arcy Concession}

More than a century has elapsed since the early beginnings of the oil industry in Iranian sedimentary basins. Officially it commenced with the concession granted to William Knox D'Arcy (He was a British citizen, and an 
entrepreneur and financier who had made a fortune in gold mining in Australia) by Muzaffar al-Din, Shah of Ghajar, on 28 May 1901 (Chapman, 2004).

The first concession ever granted in the whole of the Middle East was the exclusive rights to oil exploration of the entire country except the five Northern provinces of Azerbaijan, Gilan, Mazandaran, Astarabad, and Khorasan. The first site chosen for exploration was at Cia Sork and southern Shooshtar region, an almost inaccessible plateau in the mountains of western Persia, north of Qasr -e Sirin.

Work proceeded but mounting expenditure forced D'Arcy to seek financial backing in order to keep the concession afloat. By April 1904, less than three years after its inception, the venture was on the verge of collapse (Ferrier, 1982).

D'Arcy succeeded in solving his financial difficulties through the involvement of a British company, Burma Oil, (named after its concession operations in Burma), based in Glasgow. (Ferrier, 1982) D'Arcy's protracted negotiation with Burma Oil resulted in the formation of a new company, Concession Syndicates Ltd, in mid-1905, with financial and technical support provided by Burma Oil. D'Arcy's operation became a subsidiary, and he was a director of the new enterprise (Corley, 1983).

The first commercial oil discovery was recorded in the Masjid-e-Solaiman concession area on 26th May 1908.(Alfred, 2012) Shortly after discovering this huge oil field the Anglo-Persian Oil Company (APOC) was established and later became the Anglo-Iranian Oil Company (AIOC) in 1935, and better known today as British Petroleum (BP) (Mafi, 2008).

According to the concession, the concessionaire enjoyed the exclusive right to explore, develop, exploit and transport petroleum in return for which the Iranian government was entitled to 16 percent of the net profit on all operations. The Iranian media and Reza Shah (Shah of Iran) objected to the concession after the First World War because little money was paid to the Iranian government, causing acrimony in the conduct of the agreement.

\section{The 1933 Concession Agreement}

By the late 1920s the APOC was seeking a 20-year extension of the original 1901 concession. Consequently a special commission was established for the purposes of negotiation. Negotiations mission were carried out by a 'Taimoortash' (First Minister of Court) on behalf of the Iranian Government and the commission's aim was renegotiation and renewing the conditions (Malek, 2016).

The result of negotiations was that each party insisted on including their own terms and this led to stalemate. After several years meeting (until 1931), finally the AIOC and Iranian government agreed to the key specifications of the 1933 concession as follows:

- Payment of 750.000 pounds annually (a minimum guaranteed) plus a royalty (4s gold per ton) of oil produced;

- Payment of tax to Iran (four percent with a minimum guaranteed tax of 230.000 pounds annually);

- Iran's representation on the board;

- Payment of one million pounds (by APOC) as settlement of all past claims;

- Reduce the allowable area of exploration to 100.000 square miles

- Full cancellation of the exclusive right for the transportation of oil, 20 percent of the share to Iran;

- Cheaper oil for Iranians (Malek, 2016).

With the implementation of the 1933 agreement, the royalties for 1931 and 1932 were recalculated on the new basis, with the result that 1,339,132 pounds sterling (US \$5,758,267) was eventually paid for 1931, in lieu of the amount of 306,872 pounds sterling (US $\$ 1,319,549$ ) that had caused so much vexation. The Iranian government's revenues from oil sold inside and outside the country increased from an average of 12.3 US cents a barrel during 1913-1932 to an average of 21.5 cents in the period 1933-June 1951. The total amount of the revenues rose from \$5.7 million in 1929 (116 thousand barrels per day) to $\$ 10.3$ million in 1936 (171 thousand b/d). Finally, it rose to $\$ 44.8$ million in 1950 (664 thousand b/d) period (Yeganeh, Najmabadi and Mina, 1991).

\section{From Nationalisation to ReVolution (1951-1979)}

Before the 1951 Nationalisation of the Iranian Oil Industry, all operations were conducted by the foreigners and the government played the role of a bystander, but these circumstances changed and after the passage of the Nationalisation law (1951), the Iranian government went to the other extreme by controlling all operations of exploration, extraction and exploitation.

The grave economic and political conditions that ensued in the subsequent years demanded modernisation. Thus, it was decided to encourage the flow of foreign investment in oil, but at the same time provide for Iran's participation through some kind of partnership with foreign oil concerns. 


\section{Nationalisation}

The first anti-concession proposals had been written and submitted to Iranian Majlis (Parliament) by the leader of the National Front of Iran's party (Dr Mohammad Mosaddegh) in December 1944. But because of World War II and many complex security issues relating to Iran and its allies, issues related to nationalisation were put on hold until after the war.

In the post-World War II period Iranian dissatisfaction with the level of oil revenues was greatly aggravated by the growing annoyance at the fact that the British government was extracting more income from APOC through taxation than the Iranian government was obtaining from the exploitation of Iran's national resources. For example, in the years 1945, 1946, and 1947, Iranian revenue (including royalties and taxes) amounted to 5.62, 7.13, and 7.10 million pounds respectively, while British government taxation reached 15.63, 15.59, and 16.82 million pound respectively for those three years (Bamberg, 1982).

A set of reasons, including financial inequalities and rampant poverty in Iran, gave rise to a nationalistic movement in Iran. During this time Dr Mosaddegh was appointed as the new Iranian Prime Minister on 27th April 1951. Then Mosaddegh cemented the link between Iranian oil and Iranian nationalism. This resulted in a change of the symbolism of oil issue from a fungible commodity to a political symbol. Mosaddegh immediately submitted the draft of the new Petroleum Law to the Majlis, incorporating some of his previous ideas and policies on nationalisation (Walden.1962). It became law on 29th April 1951 and was applied with immediate effect. Within a month the National Iranian Oil Company (NIOC) had been established, and the nationalisation of the Iranian oil industry was initiated (Otman, 2007).

The nationalisation of Iran's oil industry generated much domestic and foreign argument as to the reasons why the Iranian Parliament decided to revise the structure of the oil concession framework. This thesis argues it was Iran's recent independence, its desire to earn higher oil revenues and the wish for more direct participation by the national government. This placed heavier financial burdens and greater risks on the international companies (Mafi, 2008).

The major objectives of Iran's nationalisation consisted of: the establishment of Iran's sovereignty, ownership and control of the country's oil industry and resources; the eradication of foreign political and economic influence in Iran; the mobilisation of financial resources for the implementation of the country's development plans, which needed to be financed largely from the oil revenue and foreign borrowing and that the government sought to control all operations of exploration, extraction, and exploitation (Ramazani, 1962).

Nationalisation had dramatic and enduring consequences. In the summer of 1953, the coup d'état, known in Iran as the 28 Mordad Coup (also known as Operation Boot or TPAJAX Project) ended in the downfall of Mossadegh and restored the Shah to power (Otman, 2007).

\section{The 1954 consortium oil agreement}

With the return of the Shah and the instalment of new (Zahedi) government, the stage was set to bring Iranian oil back into production and onto the world market. But the main question was: how was this to be done? The only answer is: The AIOC. For it to take the lead would only re-ignite the nationalist fires in Iran. Clearly the US government would have to lead the way to an oil settlement. The U.S. government retained as special representative the Secretary of State (Herbert Hoover) to see if a new consortium of oil companies could be created to take up the AIOC's interests. Subsequently, the Anglo-American inter-company talks ended with the signing of a Memorandum of Understanding (MOU) on 9 April, 1954 (Toloui, 1993).

The MOU create a consortium in which the shares would be: 40 percent for AIOC (changed to British Petroleum Company in December 1954, 14 percent for Royal Dutch-Shell, 8 percent each for the five U.S. companies (Standard Oil (NJ), Socony, Socal, Texas and Gulf) and 6 percent for Compagnie Française des Pétroles (CFP) (Mohaddes and M Hashem, 2013). On the formation of the consortium and for the future operation of the Iranian oil industry, the negotiations moved to Tehran, after agreement had been reached in London. Howard Page of Standard Oil was head of the consortium negotiating team, and the Iranian delegation was led by Dr 'Ali Amini', the finance minister. The oil agreement was finally signed after four months of intensive negotiations on 19 September 1954 in it had been approved by parliament.

The new contract's profits made from the oil operations under the agreement were to be divided equally between the consortium and the Iranian government, preserving the principle of 50/50 profit sharing that had become the norm in the Middle East. This contract had a basic twenty-five-year term, with a provision for automatic renewal for fifteen years. The contract also required the consortium to relinquish exclusive exploitation rights to 20 percent of the area it controlled after each five-year extension period (Otman, 2007). 
While this agreement was an improvement over the 1933 concession, it again failed to live up to Mossadeq's promise that securing control of Iran's own oil meant controlling its own destiny. It was obvious that NIOC still did not have total control over output or marketing (Brumberg, 2007).and it left the Iranian government as owner with no rights (O'Connor, 2010) The long reviled British and newly despised Americans were still meddling in Iran's domestic politics. Most importantly, the fact that the agreement was accepted by an increasingly autocratic and unpopular Shah, rather than Mossadeq, meant that what could have been considered a triumph for Iran was perceived rather as a humiliation (Heiss, 1997). Finally, the fact cannot be denied that the 1954 Agreement failed to achieve the main objective of the 1951 oil nationalisation.

\section{The 1957 Petroleum Law}

The first petroleum law in Iran was enacted on 1957 in the years immediately following the signing of the 1954 Consortium Agreement. Three years after consortium and while negotiations were being conducted between NIOC and Azinda General Italiana Petrole (AGIP) Mineraria (the upstream arm of the Italian State Oil Company (ENI) the first Petroleum Act was drafted and submitted to the Parliament and then it was ratified by it and was promulgated on 31st July, 1957 (Wall, 1958).

The discovery of the some oil and gas fields by the Iran Oil Company was the result of action by the fledgling national Iranian oil and gas industry. The company set up during the First Plan to explore and exploit petroleum, not only proved Iran's growing technical capacity but it also helped to give Iran a prestige not hitherto enjoyed by any other oil producing and exporting country. Against this background it is therefore hardly surprising that some famous International Oil Company (IOC) like ENI decided to look for oil supplies in the Middle East by offering new contractual terms. Since access to crude oil resources was of utmost importance for Italy and ENI, a way had to be found for entry into the Middle East oil scene. NIOC and ENI thus pioneered a new form of contractual relationship, thereafter known as 75/25 profit sharing or better known today as Production Sharing Agreement (PSA), breaking the hallowed fifty-fifty arrangement and heralding a new era in international oil agreements.

However, a basic and important question is what had prompted Iran's governors to enact the 1957 Petroleum law? And what was its aim?

In July 1957, the parliament passed a new Petroleum Law for encouraging of private investment in Iran's oil industry. It was aimed at providing a different basis for Iranian oil operations, in essence a middle way between the concession system, where the Iranian Government had to assume the role of a bystander and rent collector, with no control over the management or direction of this most strategic industry, and the opposite extreme epitomised by the Nationalisation Law of 1951.

In addition The Petroleum Act had for its objective the rapid exploration and extraction of petroleum throughout the country and the continental shelf (excluding the consortium area) and the downstream activities such as refining, transportation, and sale of petroleum so obtained (Wall, 1958). For this purpose the NIOC was permitted to enter into contractual relationships with persons, Iranian or foreign, possessing the requisite technical and financial competence, with the aim of developing the hydrocarbon resources of Iran (Daniel, 2007).

The most important feature of this law is permission of set-up to joint ventures with government participation that the minimum share for NIOC participation in any of the ventures had to be 30 percent.

The oil contracts which were conducted between NIOC and IOC after the passing of the 1957 law are following; the first, in 1957, was with the Italian Government-owned A.G.I.P. Mineria, which provided for the formation of an Iranian company, Société Irano-Italienne des Pétroles (SIRIP) (Vassiliou, 2009). A second oil contract was endorsed between Iran with Pan American Petroleum Corporation and it led to the formation in 1958 of the Iran Pan American Corporation (IPAC) (Yeganeh et al., 1991). Also the fiscal terms was another one of the significant term of these contracts, which appeared to give the NIOC 75 percent of net profits realised from the investment - fiscal terms which were unheard of at this time in petroleum investments. In fact as 'Otman' said; the new contracts were participation agreements in which the Second Party (IOC) shared risks and rewards equally with the NIOC. But because the Second Party had to pay 50 percent of its share of profits as tax to the government of Iran, it effectively meant that 75 percent of profit share went to Iran and 25 percent to the Second Party. However the Second Party still received 50 percent of profits realised from its actual investment (Otman, 2007).

The government has taken the decision to open a part of the continental shelf of the Persian Gulf for international bidding, based on the success and experience gained by NIOC with the implementation of SIRIP and IPAC agreements, and given the ambitious nature of the Government's development plans and economic growth objectives. The significance of this round of bidding went well beyond the figures associated with bonuses and exploration obligations. This approach led to be a significant success. A major oil company, had broken rank with 
other major companies and accepted the concept of participation. This, too, proved to be forerunner of many new agreements leading eventually to the Organisation of the Petroleum Exporting Countries (OPEC)'s resolution and participation in September 1971.

NIOC once again pioneered an Agency Agreement (a new type of contractual relationship), where under the operator, ERAP (Entreprise de Rechereche et d'Activités Pétrolières, French State Oil Company) carried the status of a contractor without any ownership rights to production (Mohammad Yeganeh, Najmabadi and Mina, 1991). The main features of this agreement were the following:

- Rendering of technical, financial and commercial services were undertaken by ERAP;

- NIOC has financial responsibility for agreement which covered operations, it being understood that all funds required for exploration, appraisal, and development operations were to be supplied by ERAP until the cash flow accruing to NIOC as a result of the operations would be sufficient to enable NIOC to provide the financing of appraisal and development;

- If a commercial field were to have been discovered and commercial production were to have commenced, NIOC were to become liable for the repayment of all funds advanced by ERAP;

- The oil produced was entirely owned at wellhead by NIOC;

- In case of commercial discovery ERAP was to be reimbursed out of part of production for the loans extended to NIOC, while it was also entitled to purchase a certain quantity of production at a discounted price as remuneration for services rendered;

- NIOC was the owner of all the assets created or used in connection with the operation;

- The tax status of ERAP was that of a purchaser of oil, making no profit in Iran (Yeganeh et al., 1991).

\section{The 1974 Petroleum Law}

Every law and legislation has its own individually rational reason for approving. The reason of any law could be affected by social situation, economic issues, domestic or international conditions or has a long history. Historically, before the 1974 petroleum law, the global oil price was low until the late 1960s but there was an almost threefold increase in crude oil prices from 1970-74, from US\$ \$3.39 to US\$9.35 / bbl. This led to excessive profits for the oil companies and caused an approach from Iran as host country to change terms of petroleum contract.

So, in order to further enhance its control and management of the petroleum operation carried out on its behalf by qualified operators, the NIOC drafted a new and innovative Petroleum Act in 1974, which was approved by the Council of Ministers and enacted by the Parliament. 1974 was the year in which Iranian oil production reached its historical peak at $6.021 .6 \mathrm{~mm} \mathrm{~b} / \mathrm{d}$ (OPEC, 'Annual Statistical Bulletin, 2012). It was also the year in which a new Iranian Oil Act, which amended the 1957 Petroleum Law, came into force. This new law envisaged that exploration and production agreements with foreign oil companies could only be concluded on the basis of Risk Service Contracts (RSC) under which the contractor had no ownership right either to the reserves discovered or to the production from the agreement area. In a telling clause (Section 1 of Article 3) it was stipulated that "the petroleum resources and the petroleum industry of Iran belong to the nation. The exercise of the Iranian nation over the petroleum resources of Iran with respect to the exploration, development, production, exploitation and distribution of petroleum throughout the country and its continental shelf is entrusted exclusively to the National Iranian Oil Company who shall act thereupon directly, or through its agents and contractors." As was mentioned above, in this Act the concept of "Risk Service Contract" was introduced for the first time in Article No.3. In this contract the contractor (IOC) had to conduct upstream exploration entirely at its own risk, and had no right to the reserves discovered or to the production from any field developed. If exploration led to a commercial discovery, the IOC had to develop the oil field under the supervision of the NIOC. Thereafter for a stipulated period not exceeding fifteen years, the NIOC would sell 50 percent of the production to the IOC at a discount, enabling it to recover its original investment plus a reasonable return on investment.

The 1974 petroleum law prohibited the IOCs from ownership of hydrocarbon resources and stipulated terms restricted solely to the NIOC and the terms of all the Participation Contracts made under the 1957 Law were completely amended in line with Article 19 of this law.

Increasing royalty payments from 12.5 to 20 percent and tax payments from 50 percent to 80 percent was brought by the new law. The Oil prices with specific crude oil types were henceforth determined by OPEC. These moves severely impacted the profitability of the IOC's operating in Iran, although production was sustained (5.534 b/d) in those years (1975-78) (Otman, 2007). 


\section{LEGAL AND COMPARATIVE ANALYSIS}

This section devoted to legal and comparative analyses of Iran's oil and gas legal framework which divide to two period; period one that consist of the D'Arsy concession and 1933 concession agreement as a pre-nationalisation period and second period that includes oil and gas contractual from nationalisation to revolution period.

In pre-nationalisation period (the D'Arsy concession and 1933 concession agreement) it emphasises the importance and exclusive privilege of these agreement from the perspective of the foreign participants and the attempts to renegotiate these unbalanced contracts due to lack of particular legislative framework and domestic public pressure as well. So, any agreement about oil and gas was subject to Shah of Iran (Iranian ruler) for lack of clear rule and legislation.

However, after the nationalization until revolution, Iran's oil and gas industry had experienced different petroleum contractual regimes such as "profit agreement" in 1954 consortium agreement, "production sharing agreement" in 1957 petroleum law and "Risk service contract" in 1974 petroleum law. Special attentions about comparative analyses of those contractual regimes are given to three fundamental issues regarding the legal framework, ownership, duration and payment.

\section{Ownership}

According to the 1954 consortium agreement and PSA (in 1957 petroleum law) once the petroleum reached wellhead its ownership was transferred to the consortium and IOC in respectively, whereas based on RSC (in 1974 petroleum law) IOC is not entitled to any oil neither in the reservoir nor even at wellhead in contrast with concession and PSA.

\section{Duration}

Based on the 1954 consortium agreement duration of agreement was for 25 years with the provision for automatic extension for up to another 15 more years, while in 1957 petroleum law the contract were for a period of 25 years with compulsory relinquishment requirements, however duration terms of the 1974 petroleum law was totally different. The 1974 petroleum law stipulated that contract terms is divided to exploration and exploitation operation, the former being extendable for another five years period.

\section{Income}

The principle of 50/50 profit sharing between the Iranian government and the consortium was agreed in the 1954 consortium agreement. Iran's share incomes from sale of oil, including income taxes and the value of 12.5 percent royalty oil calculated at posted prices. Based on the 1957 petroleum law (PSA) the financial terms was a remarkable terms, which appeared to give the NIOC 75 percent of net profit realised from the investment. In fact participation agreement in Iran as it mentioned were 50/50 ration, where 50 percent of share was the property of the NIOC while the remaining 50 percent belonged to IOC. The Iranian government acquired half of the IOC's shares as tax. In effectively meant that Iran's income was 75 percent of profit share and 25 percent went to IOC. And also according to the 1974 petroleum law Iran's income increased by royalty payment from 12.5 to 20 percent and tax payment from 50 to 80 percent.

\section{CONCLUSION}

This study reviewed the history, policy and Iran's petroleum, oil and gas contractual framework from start of the exploration to the time of revolution; it seems that Iran suffered tension and conflict. To transition from individually negotiated agreements to nationalisation and from nationalisation to revolution was valuable but costly. During these times, three types of oil and gas contracts have been experienced in Iran; concession, product sharing agreement and service contract. The concession agreement was specific to the period from Iran's oil discovery up till nationalisation. The other two kinds of oil and gas contractual framework were approved in the 1957 Petroleum Law (product sharing agreement) and in the 1974 Petroleum Law (risk service contract).

Finally it should be mentioned that all those petroleum contractual regimes were a turning point in that time.

\section{ACKNOWLEDGMENTS}

I profoundly grateful to God to giving me the scientific merit and I am sincerely thankful to my parents for their spiritual support. My thanks goes to Law Faculty of Shahid Beheshti University for the financial support of this research and my thanks also goes to Hamid Reza Nikbakht Fini (Head, department of International Commercial Law, Faculty of law, Shahid Beheshti University) and Michael Adams (Dean of School of Law, Western Sydney University) and particularly to David Sinfield (Law Librarian, Western Sydney University) for their thoughtful comment and writing assistance. 


\section{REFERENCES}

Bamberg, John H. (1982), The History of the British Petroleum Company (Cambridge, 1982).

Chapman, Simon (2004), Oil in Middle East and North Africa (Europa publication, 50 ${ }^{\text {th }}$ ed, 2004) 116.

Corley, Thomas Anthony Buchanan (1983), A History of the Burmah Oil Company (London, 1983) 87.

Daniel, Brumberg (2007), The National Iranian Oil Company In Iranian Politics, Prepared in conjunction with an energy study sponsored by Japan petroleum centre and the James A. Baker III institute for public policy rice university 14 .

Ferrier, Ronald W (1982), The History of the British Petroleum Company (Cambridge, 1982) 163.

Heiss, Mary Ann (1997), Empire and Nationhood: The United States, Great Britain, and Iranian Oil, (New York: Columbia University Press, 1997).

Jerrold L. Walden, (1962), 'The International Cartel in Iran: Private Power and the Public Interest' 11 Journal of Public Law 23.

Kamyar Mohaddes and M Hashem, (2013), 'One Hundred Years of Oil Income and the Iranian Economy: A Curse or a Blessing?' 150 social science research network 7 .

Mafi, H. (2008), 'Iran's Concession Agreements and the Role of the National Iranian Oil Company: Economic Development and Sovereign Immunity' 48 Natural Resources Journal 409.

Malek, Mohammad (2016), 'Oil in Iran between the Two World Wars' (9 March 2016) Iran Chamber Society <http://www.iranchamber.com/history/articles/oil_iran_between_world_wars.php >.

Mostafa, Elm. (1992), Oil, Power, and Principle: Iran's Oil Nationalization and Its Aftermath. Syracuse.

Nasrollahi Shahri, Nima (2010), 'The Petroleum Legal Framework of Iran: History, Trends and the Way Forward' 8 china and Eurasia quarterly, 113

O'Connor, Harvey (2010) 'How the international oil cartel carved up the oil resources of Iran after the overthrow of Mossadegh; A full account of a little-known story by an expert in the oil-industry field: The Iranian Oil Grab'(2010) 12 <http://www.marxists.org/history/etol/newspape/amersocialist/amersoc_5504-a.htm>.

OPEC, 'Annual Statistical Bulletin'( 2012)

Otman, W A (2007), 'The Iranian Petroleum Contract: Past, Present and Future Perspectives' 44(5) Oil, Gas E Energy Law Intelligence 5-9.

Ramazani, Rouhollah .K (1962), Choice-of-Law Problems and International Oil Contracts: A Case Study, 112 The International and Comparative Law Quarterly 516.

Randy Alfred, (2012), 'May 26, 1908: Mideast Oil Discovered - There Will Be Blood' (21 march 2012) http://www.wired.com/2008/05/dayintech-0526/.

Toloui, Mahmoud Power game ( 1993), Oil War in the Middle East (Tehran Elm Publication, 1993) 127.

Vassiliou, M S (2009), The A to Z of the Petroleum Industry (Scarecrow Press 2009) 264.

Wall, E H (1958), The Iranian-Italian Oil Agreement of 1957, The International and Comparative Law, 7 (4) Quarterly 786.

Yeganeh, Mohammad; Najmabadi, Farokh and Mina, Parviz (1991), 'The Development of The Iranian Oil Industry' (Proceedings of the Conference held at the School of Oriental Studies London in March 1990, Published by Society for Contemporary Iranian Studies, Middle East Center, University of London, 1991) 52-53. 
